The Rise of

Female Kings

in Europe,

1300-1800 
This page intentionally left blank 


\section{The Rise of}

\section{Female Kings}
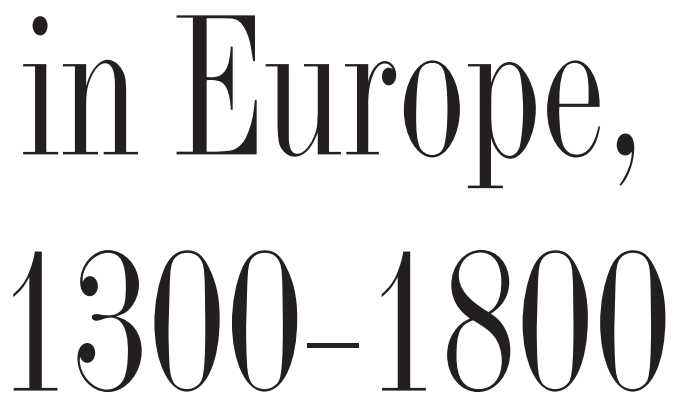

\section{William Monter}

Yale UNIVERSITY PRESS NEW HAVEN AND LONDON 
Published with assistance from the foundation established in memory of Calvin Chapin of the Class of 1788 , Yale College.

\section{Copyright (C) 2012 by Yale University.}

All rights reserved.

This book may not be reproduced, in whole or in part, including illustrations, in any form (beyond that copying permitted by Sections I07 and I08 of the U.S. Copyright Law and except by reviewers for the public press), without written permission from the publishers.

Portions of chapter 2 appeared earlier in the Journal of Interdisciplinary History, XLI (20II), 533-64. They are included herein with the permission of the editors of the Journal of Interdisciplinary History and the MIT Press, Cambridge, Massachusetts. Copyright 2oII by the Massachusetts Institute of Technology and the Journal of Interdisciplinary History, Inc.

Yale University Press books may be purchased in quantity for educational, business, or promotional use. For information, please e-mail sales.press@yale.edu (U.S. office) or sales@yaleup.co.uk (U.K. office).

Set in Adobe Garamond type by IDS Infotech, Ltd. Printed in the United States of America.

Library of Congress Cataloging-in-Publication Data

Monter, E. William.

The rise of female kings in Europe, I300-I80o / William Monter.

p. $\mathrm{cm}$.

Includes bibliographical references and index.

ISBN 978-0-300-I7327-7 (hardcover: alk. paper)

I. Europe-Kings and rulers-History. 2. Queens-Europe-History.

3. Empresses-Europe-History. 4. Women-Political activity-Europe-History.

5. Monarchy-Europe-History. 6. Inheritance and succession-Political aspects-Europe-History. 7. Europe-Politics and government-476-I492.

8. Europe-Politics and government-I492-I648. 9. Europe-Politics and government-I648-I789. Io. Europe-Politics and government-I789-I8I5.

I. Title.

D217.M57 2012

940.09 '9- dc22

2011014263

A catalogue record for this book is available from the British Library.

This paper meets the requirements of ANSI/NISO Z39.48-1992

(Permanence of Paper). 
For my wife, Rosellen-photographer, chauffeur, cartographer, informed critic-and my daughters, Elizabeth and Onnie 
This page intentionally left blank 